\title{
Resource Industries of the Far East: Manifestations of the Current Crisis and Their Fundamental Causes
}

\author{
Natalia E. Antonova and Natalia V. Lomakina* \\ Economic Research Institute of FEB RAS \\ Khabarovsk, Russian Federation
}

Received 25.05.2021, received in revised form 15.06.2021, accepted 29.06.2021

\begin{abstract}
The article focuses on the manifestations of the modern «pandemic» crisis in the key resource industries (mineral resources and forest complexes) of the Far Eastern macroregion. The features of the crisis dynamics of production are shown depending on the predominance of some types of natural resources in the structure of the regional economy, their connection with Russian and world markets, the character of the impact of market factors. The influence of external shocks and national institutional imperatives on the change in the parameters of different branches of the natural resource sector has been investigated. There were found new crisis manifestations associated with the peculiarities of staff formation in the resource sector («shift workers factor»), their consequences for the regional economy and raw materials companies, the need to update the relevant scientific and methodological assessments and management decisions. It was revealed that with all the novelty and multidirectionality of manifestations of the crisis in 2020, the key characteristics of the situation are determined by the traditional set of fundamental reasons that define the development of a region with a resource specialization both in crisis and recovery periods.
\end{abstract}

Keywords: economic crises, external shocks, resource industries, mineral resources and forest complexes, production dynamics, structural problems, institutional shocks, Far Eastern Federal District.

Research area: economics.

Citation: Antonova, N.E., Lomakina, N.V. (2021). Resource industries of the Far East: manifestations of the current crisis and their fundamental causes. J. Sib. Fed. Univ. Humanit. Soc. Sci., 14(7), 978-986. DOI: $10.17516 / 1997-1370-0777$.

\footnotetext{
(C) Siberian Federal University. All rights reserved

* Corresponding author E-mail address: antonova@ecrin.ru, lomakina@ecrin.ru ORCID: 0000-0003-0317-0817 (Antonova); 0000-0003-3490-5775 (Lomakina)
} 


\title{
Ресурсные отрасли Дальнего Востока: проявления современного кризиса и их фундаментальные причины
}

\author{
Н.Е.Антонова, Н.В.Ломакина \\ Институт экономических исследований ДВО РАН \\ Российская Федерация, Хабаровск
}

\begin{abstract}
Аннотация. Исследованы проявления современного «пандемийного» кризиса в ключевых ресурсных отраслях (минерально-сырьевой и лесной комплексы) Дальневосточного макрорегиона. Показаны особенности кризисной динамики производства в зависимости от преобладания отдельных видов природных ресурсов в структуре региональной экономики, связанности их с внутренним и мировым рынком, характера воздействия рыночных факторов. Исследовано влияние внешних шоков и национальных институциональных императивов на изменение параметров отраслей природно-ресурсного сектора. Показаны новые кризисные проявления, связанные с особенностями формирования персонала в ресурсном секторе («фактор вахтовиков»), их последствия для региональной экономики и сырьевых компаний, необходимость актуализации соответствующих научно-методических оценок и управленческих решений. Выявлено, что при всей новизне и разнонаправленности отдельных проявлений «пандемийного» кризиса 2020 г. ключевые характеристики ситуации определяются традиционным набором фундаментальных причин, определяющих характер развития региона с сырьевой специализацией как в кризисные, так и в восстановительные периоды.
\end{abstract}

Ключевые слова: экономические кризисы, внешние шоки, ресурсные отрасли, минерально-сырьевой комплекс, лесной комплекс, динамика производства, структурные проблемы, институциональные шоки, Дальневосточный федеральный округ.

Научная специальность: 08.00.00 - экономические науки.

\section{Introduction}

Despite the fact that by 2020 the forecasts of experts about the approaching of the next large-scale crisis had already «walked around the world», in the reality the reasons, the speed of its start and the forms of its manifestation turned out to be extremely unexpected. The economic crisis of 2020 is global in nature: with the spread of the pandemic there began a large-scale drop in demand, a forced halt of economic activity with a reduction in the income of both business and the population.

The same processes were taking place in Russia, whose economy found itself under the simultaneous impact of two external shocks: 1) deterioration of foreign trade conditions due to the fall in oil prices; 2) a sharp decline in economic activity due to restrictions associated with containing the spread of the pandemic. It is known that the characteristics of the subsequent equilibrium state of the system are strongly influenced by the path dependence effect (Puffert, 2003). The trend of «extinction» of economic growth preceding the crisis in 2020 led to the fact that the Russian economy approached the «pandemic» crisis in a state of «recovery stagnation» (Minakir, 2020a).

The causes and consequences of modern crises, the directions of their impact on the Russian economy (Aganbegian, 2016; Minakir, 2016; Chereshnev, Tatarkin, Fedorov, 2012), individual industries and regions (Malkina, 2018; 
Mikheeva, 2019) are studied by many scientists, including corresponding assessments for the current «pandemic» crisis (Aganbegian et al., 2021; Kravchenko, Iusupova, 2020; Minakir, 2020b).

The consequences of the crisis in a particular region depend on the structure of its economy and the degree of connection with the global economy. Certain features of the manifestations and consequences of crises in resource industries and regions (countries) in whose economy these industries predominate have already been enlisted (Guriev et al., 2010; Malkina, 2018). The economy of the Far Eastern macroregion is mainly characterized by raw materials specialization, therefore, the task of this article is to identify the features of the manifestation of the modern «pandemic» crisis in key resource industries (mineral resources and forest complexes).

\section{Mineral resource complex: crisis dynamics and prospects}

The mineral resource complex (MRC) of the Far East belongs to the industry of regional specialization, which is measured not only by the value of some economic indicators (its share in GDP, in the structure of industry, etc.), but also by the role of key types of mineral resources mined in the Far Eastern Federal Dis- trict (FEFD) and playing a major role in the national economy (diamonds, gold and silver, oil and gas, coal).

For most regions in the FEFD, MRC is the framework of their industrial production, the budgetary and often the city-forming sector of the economy. Therefore, the assessment of the manifestations of the current crisis of 2020, the search for their connection with the fundamental factors of the development of this complex in the Far East region goes beyond the scope of only an industry goal.

The first thing that requires consideration and discussion is the dynamics of production in MRC and its change in connection with the crisis of 2020. If we analyze the indicators of the production index by economic activity (EA) «Mining» as a whole for the Far Eastern macroregion, then its movement in 2020 almost completely repeats the all-Russian trend, but the depth of the index fall is slightly less (Fig. 1a). However, this is a false conclusion, since when considering this indicator separately for the regions of the FEFD, the picture is different (Fig. 1).

Such a multidirectional movement of production indices in EA «Mining» in different regions in 2020 (Fig. 1a and 1b) is due to a number of reasons and, first of all, the structure of the MRC in the territory. We have grouped the re-
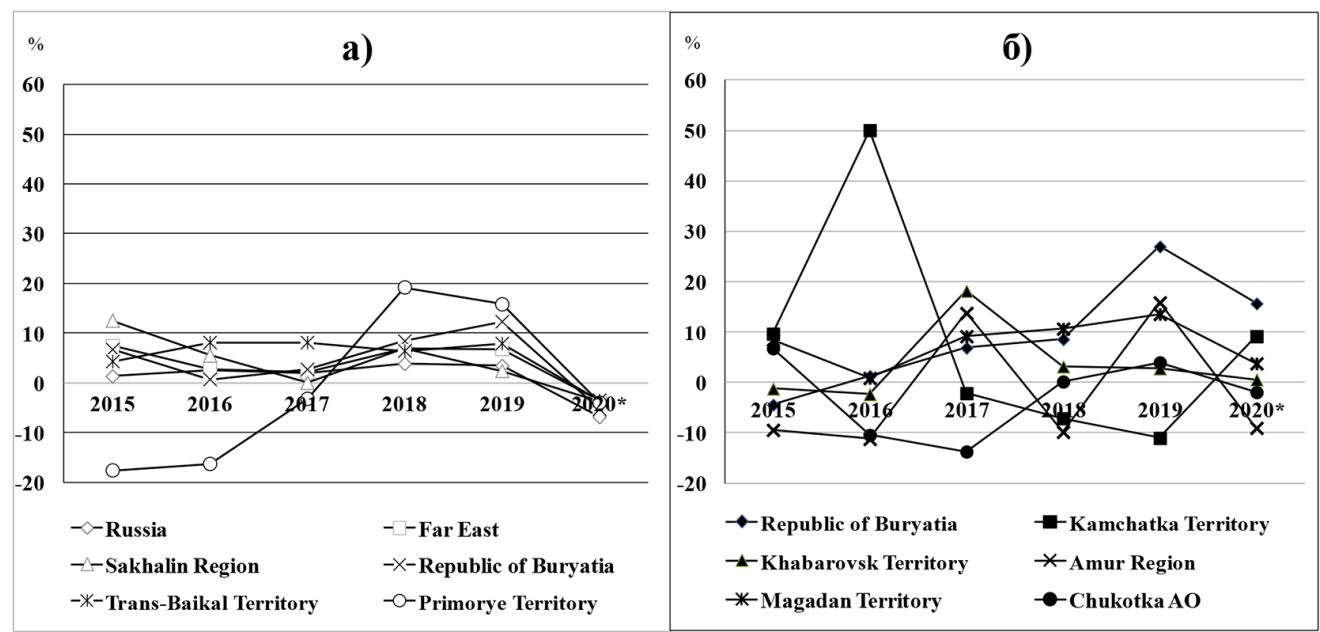

Fig. 1. Dynamics of economic activity «Mining» in the FEFD, in\% to the previous year. Source: calculated according to data of Federal State Statistics Service. Available at: https://rosstat.gov.ru/enterprise_industrial 
gions according to the concentration of various types of mined mineral resources in the structure of EA «Mining». The first group (Fig. 1a) includes regions in the structure of which the extraction of fuel and energy resources (oil, gas, coal), precious stones (diamonds), nonferrous and ferrous metals prevails. The second group (Fig. 1b) shows the regions with a predominance of the extraction of precious metals (mainly gold) in the MRC.

Consideration of production trends in the EA «Mining» for the selected groups of regions is justified by the nature of the influence of the crisis factors of 2020 on the demand and price dynamics of various types of mineral resources.

As for the first group of regions (Fig. 1a), the negative dynamics of production was mainly determined by market factors: a catastrophic drop in prices and demand for oil (Sakhalin Oblast: $-3.8 \%$ ); loss of interest in luxury goods amid the growing epidemic (in Yakutia, which provides $25 \%$ of the world diamond market, the drop was $-5.3 \%$ ); a decrease in demand and prices for coal, non-ferrous and ferrous metals (Zabaikalsky and Primorsky Krai, the Jewish Autonomous Region showed a decline of $3.5-4.2 \%$ ).

The dynamics in the second group of regions looks quite different (Fig. 1b), with either the level of 2019 maintained (the Khabarovsk Territory, Chukotka Autonomous Okrug), or the production index EA «Mining» grown in 2020 (from $+3.8 \%$ in the Magadan Region, $+9.2 \%$ in the Kamchatka Territory to $+15.7 \%$ in the Republic of Buryatia). The positive dynamics of production in this group is due not only to the traditional role of gold in crises as an «insurance currency» and the corresponding increase in prices for it $(+24.4 \%$ for 2020 and $+35.8 \%$ five-year dynamics (Pervyi kvartal $2021 . ., 2021)$ ), but also depreciation of the ruble. The combination of these factors has more than once ensured the positive dynamics of the Far Eastern gold mining industry in times of crises (Antonova, Lomakina, 2020). The only exception was the Amur Region, where in 2020 the drop in the production index EA «Mining» was $-9 \%$ (compared with an increase of $+15.9 \%$ in 2019). According to experts, this decline was not caused by «pandemic» factors: at the enterprises of the main gold miner of the Amur Region, GK Petropavlovsk, negative production dynamics reached $-18.4 \%$, the reasons were internal financial difficulties and corporate conflicts in the company, as well as the depletion of the raw material base.

It should be noted that the state of the mineral resource base, its depletion and reproduction (through the starting of new investment projects) are among the fundamental reasons for the formation of trends in the dynamics of production in the gold mining industry (Kriukov, Tokarev, 2019). This is illustrated quite clearly in Fig. 1b: the Far Eastern gold mining is characterized by a «ragged» trajectory of the dynamics of production throughout the period under consideration 2015-2020, both in value and in physical terms (Table 1).

Sanitary and epidemiological restrictions and their consequences have become a new factor influencing the economic situation of mining companies in the context of the current crisis. According to the Ministry for the Development of the Russian Far East, about a thousand enterprises in the Far East use shift work, the number of employees at them is about 150 thousand people. The «shift workers factor» manifested itself in the inability to provide necessary amount of production due to restrictions on inter- and intraregional transportation, the emergence of local foci of infection in companies in remote areas of the Far Eastern macroregion, additional costs for companies and regional authorities to meet epidemiological requirements. For example, according to estimates, the «coronavirus» expenses of companies whose assets are located mainly in the Siberian and Far Eastern Federal Districts amounted to: Polymetal - \$19.6 million (\$10 / $\mathrm{oz}$ and $\$ 3.4$ million in support to medical institutions) or $0.7 \%$ of revenue; Polyus - $\$ 155$ million or $3.1 \%$ of revenue (Itog 2020 goda ..., 2021).

Against the backdrop of the pandemic crisis, serious concerns are raised by investment strategies in the industry - both in terms of the implementation of new projects and in terms of the reproduction of the mineral resource base. However, so far large companies have 
Natalia E. Antonova and Natalia V. Lomakina. Resource Industries of the Far East: Manifestations of the Current Crisis...

Table 1. Gold mining in the main gold mining regions of the FEFD, $t$

\begin{tabular}{|l|c|c|c|c|c|c|}
\hline \multicolumn{1}{|c|}{ Region } & 2015 & 2016 & 2017 & 2018 & 2019 & 2020 \\
\hline Republic of Buryatia & 6.2 & 6.0 & 5.7 & 5.7 & 5.6 & 5.7 \\
\hline Republic of (Sakha) Yakutia & 25.3 & 23.7 & 24.8 & 28.0 & 36.5 & 39.8 \\
\hline Trans-Baikal Territory & 11.3 & 12.1 & 13.3 & 14.2 & 12.2 & 11.0 \\
\hline Kamchatka Territory & 3.6 & 6.7 & 6.7 & 5.4 & 5.8 & 6.8 \\
\hline Khabarovsk Territory & 18.2 & 19.5 & 23.1 & 24.8 & 25.2 & 24.5 \\
\hline Amur Region & 25.6 & 22.4 & 25.8 & 22.7 & 26.3 & 23.7 \\
\hline Magadan Region & 24.5 & 27.9 & 33.0 & 37.0 & 46.4 & 49.1 \\
\hline Chukotka AO & 32.1 & 28.7 & 25.4 & 24.1 & 24.5 & 24.5 \\
\hline
\end{tabular}

Source: According to the portal eRUDA.ru. Available at: http://www.eruda.ru/gdp/top-10_vedushchikh_zolotodobyvayushchikh_regiona_rf_rossii_au.htm

confirmed their investment plans: launching production at the Nezhdaninskoye gold deposit in Yakutia and commissioning the second stage of the Amur Hydrometallurgical Plant (2023) in the Khabarovsk Territory (Polymetal); development of the Klen and Kekura deposits in Chukotka (Highland Gold Mining); construction and launch by 2027 of the Baimsky GOK with a processing capacity of 70 million tons of ore per year on the basis of the Peschanka goldcopper deposit (KAZ Minerals) and a number of other projects.

\section{Forest complex:}

\section{structural and institutional problems}

In the FEFD, five of the eleven regions belong to the main forest industry regions: the Republic of Buryatia, the Trans-Baikal Territory, the Primorsky Territory, the Khabarovsk Territory and the Amur Region. These regions account for $95 \%$ of forest production and $99 \%$ of forest exports, with more than half being in the Khabarovsk Territory.

The 2020 crisis had a negative impact on the forest complexes (FC) of these regions, but these consequences were partly conditioned by their previous "path dependence». The determining factors are:

1) export-oriented production. Due to the narrowness of domestic demand, all manufactured products are exported. The main consumer for all regions is China. Therefore, the change in the situation in the Chinese market is reflected in all indicators of the $\mathrm{FC}$;
2) significant impact on the parameters of the FC of the exchange rate. Dependence on the ruble / dollar ratio often plays a positive role in crisis conditions, when a weak ruble allows timber exporters to partially compensate for the decrease in foreign exchange earnings due to falling prices and volumes in the external market;

3) predominance in the structure of production and export of raw materials or products of low value added. In the Republic of Buryatia and the Trans-Baikal Territory, annexed to the FEFD in 2018, woodworking products account for more than $90 \%$ of the product structure of exports, but they are, in fact, slightly processed raw materials;

4) localization for the FEFD of the rules of customs regulation of round wood export. In 2018 , the round wood export quotas were introduced at reduced duties for those enterprises that export a certain percentage of woodworking products. Outside the quotas, the duty increased from 25 to $60 \%$ in 2020. More than $95 \%$ of the round wood export quotas were received by only three large companies, the remaining $5 \%$ - by another $12-15$ companies. Other exporters have been forced to cut production.

All these factors influenced the activity of the FC in the pre-crisis period.

The unstable situation in the PRC market in recent years has had a strong impact on the foreign exchange earnings of timber exporters in the FEFD. In 2015, there was a drop in prices 
for the main types of forest products, partially offset by the devaluation of the ruble. This provided some stabilization in production indicators, which continued in 2016 and 2017, with indicators improving mainly due to an increase in the volume of round wood, still occupying a dominant position. But in 2018, the situation on the PRC timber market sharply deteriorated again due to the outbreak of a trade war between the PRC and the United States. Prices for almost all types of timber fell. In addition, the demand for Far Eastern timber slumped due to an increase in the round wood export duties up to $40 \%$. As a result, the foreign exchange earnings of exporters from the FEFD after 2017 began to decline (Fig. 2).

In 2019, the disadvantageous situation in the Chinese market worsened, prices for all types of products plummeted by another 25$30 \%$, the volume of exports from the FEFD decreased by $28 \%$ compared to the previous year. A particularly negative situation was seen in the Khabarovsk Territory, where in 20172019 the physical and cost volume of supplies shrank by 1.6 and 1.7 times, respectively (Antonova, Lomakina, 2020).

The toughening of customs regulations for the export of round wood forced the forest exporters of the FEFD to replace this timber, whose export had become ineffective, with woodworking products (supplied to the PRC).
As a result, its share in the forest exports of the FEFD increased to $56 \%$, for the first time exceeding raw materials in the export product structure. But this growth did not compensate for the general drop in foreign currency income of the forest complex, since the rate of decline in export volumes of round wood was higher.

The decline in the export of round wood negatively affected the production indicators of the FC of the regions. Industrial production indicators for logging began to decline, in the Khabarovsk Territory and the Republic of Buryatia this process began in 2018, and in 2019, a decline occurred in all regions (Table $2)$. On the contrary, sawn wood production showed a rise thanks to the increase in the volume of exports of this product.

The 2020 crisis had a negative impact on the forest industry in Russia. In the country as a whole, the value of exports of forest products decreased by $3 \%$, the physical volumes of exports of sawn wood - by $7 \%$, round wood - by $2 \%$ (FTS Rossii: dannyye ..., 2021).

In the FC of the FEFD, the crisis 2020 was reflected more sharply. Unlike other regions of the country, the FEFD has been «tied» in recent years to only one consumer - the PRC. Therefore, the reduction in demand in China due to a temporary halt in production and consumer activity led to a sharper drop in exports in the FC of the FEFD. The situation was aggravated

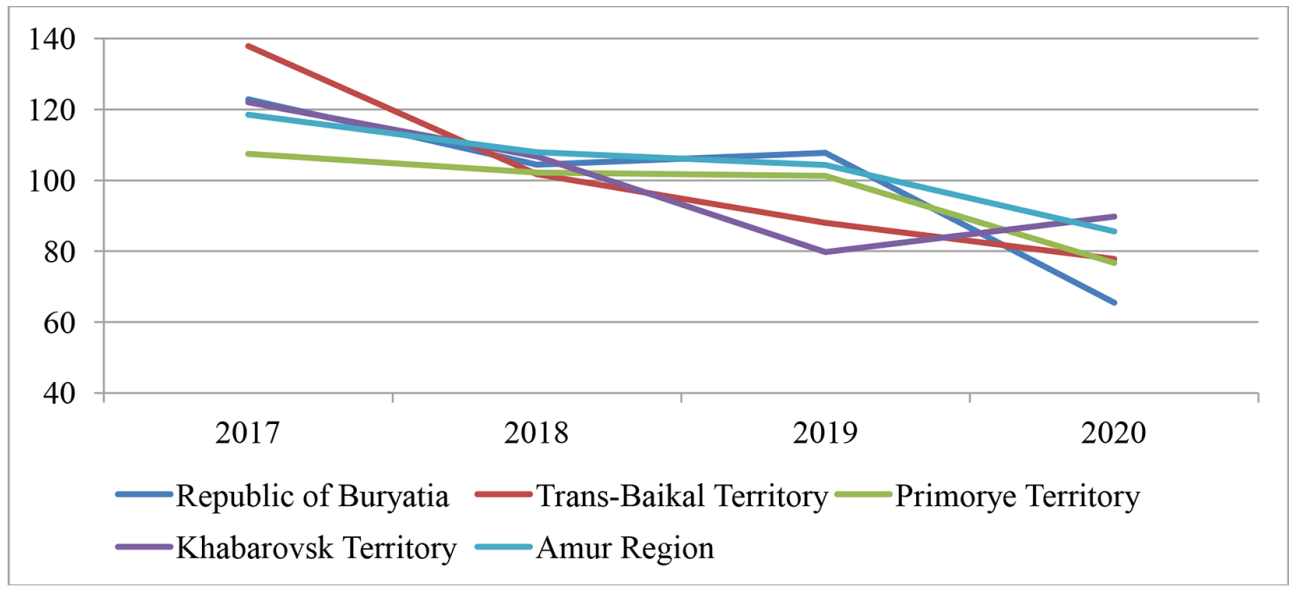

Fig. 2. Rates of change in foreign exchange earnings from the export of forest products from the regions of the FEFD, in\% to the previous year. Source: calculated based on the data of the Federal Customs Service 
Natalia E. Antonova and Natalia V. Lomakina. Resource Industries of the Far East: Manifestations of the Current Crisis...

Table 2. Production indicators of the main forest industry regions of the FEFD,\% to the previous year

\begin{tabular}{|l|c|c|c|c|c|c|c|c|}
\hline \multirow{2}{*}{ Region } & \multicolumn{4}{|c|}{ round wood } & \multicolumn{4}{c|}{ sawn wood } \\
\cline { 2 - 10 } & 2017 & 2018 & 2019 & 2020 & 2017 & 2018 & 2019 & 2020 \\
\hline Republic of Buryatia & 108.5 & 80.4 & 91.7 & 90.7 & 168.4 & 127.3 & 87.1 & 94.8 \\
\hline Trans-Baikal Territory & 101.0 & 118.0 & 85.8 & 94.9 & 96.3 & 166.1 & 107.7 & 89.2 \\
\hline Primorye Territory & 106.2 & 100.5 & 96.8 & 95.5 & 106.7 & 136.5 & 134.0 & 81.0 \\
\hline Khabarovsk Territory & 105.3 & 95.7 & 98.7 & 86.2 & 106.4 & 108.0 & 116.4 & 81.3 \\
\hline Amur Region & 122.4 & 104.1 & 96.8 & 91.5 & 99.2 & 101.6 & 112.4 & 96.8 \\
\hline
\end{tabular}

Source: calculated according to data of Federal State Statistics Service.

by the closure of checkpoints on the border between Russia and China, and the toughening by the Chinese side of phytosanitary requirements for the supply of Russian forest products (Bardal, 2020).

As a result, the total foreign exchange earnings in the FC of the FEFD lessened by $18 \%$, which was most strongly influenced by the reduction in sawn wood exports - by $23 \%$. The largest «contribution» to this decline was made by the Primorye Territory and the Republic of Buryatia, where the export of sawn wood fell by 38 and $33 \%$, respectively. In the following months of 2020, the demand for forest products in China resumed, but remained lower than in the previous year.

The volume of exports of round wood from the FEFD diminished in 2020 compared to the previous year by $10 \%$, which seems to be not so critical, but taking into account the negative dynamics in 2019, this figure was $38 \%$ in two years. That is, the crisis only exacerbated the existing negative trend.

Another negative consequence of the crisis for Russian, including the Far Eastern, forest exporters, focused on China, was the upsurge in the cost of logistics due to a shortage of containers and an almost double increase in the cost of container shipments in the Chinese direction. But once again the export-oriented complex was «rescued» by the devaluation of the ruble, which made it possible to partially compensate for the additional costs arising (Skorlygina, Mertsalova, 2020).

It can be concluded that the crisis of 2020 aggravated the already existing critical situation in the forest complex of the Far East, formed earlier by institutional innovations. From 2022, a complete ban on the export of timber from Russia is expected, which could have strong negative consequences for the Far Eastern forest complex.

\section{Conclusion}

As the study of the situation in the key resource sectors of the Far Eastern macroregion has shown, with all the novelty and multidirectionality of individual manifestations of the crisis of 2020 , there is a certain «recurrence» of it relative to the previous large-scale crises (Antonova, Lomakina, 2020; Goriunov, 2011; Lomakina, 2016). The basis of this «path dependence effect» in the new situation is the action of the «old» (fundamental) reasons: mainly raw materials specialization of the region's economy; dependence on external demand and prices on commodity markets; the formation in recent years of dependence on the «one buyer» market (China); lack of sufficient and modern processing facilities in the region; peculiarities of formation of the labour force in the resource sector (shiftworkers) and the consequences of this for the regional economy. At the same time, a relatively new «powerful» factor has been added, i. e. active changes in the institutional field of regional development.

Characterizing in general the trajectory of development of industries of the resource sector important for the economy of the FEFD during the period of acute crises and post-crisis recovery, it should be noted that, despite the difficult financial, economic and institutional conditions, these industries managed to «stay 
afloat». However, this situation is not guaranteed and does not allow counting on a sustainable return of this sector in the regional economy. «External resource demand shocks are only a pretext for crises, but the main reason is the absence of formed internal compensators and stabilizers due to an increase in produc- tion and personal consumption of businesses and households that can weaken the effect of external shocks on the economy» (Minakir, 2020a). Therefore, the issues of diversification of resource industries, their deeper embedding in the economy of the region still do not cease to be relevant.

\section{References}

Aganbegian, A.G. (2016). Osobennosti krizisnykh iavlenii v sotsial'no-ekonomicheskom razvitii Rossii [The Specificity of Crisis Phenomena in the Socio-Economic Development of Russia]. In Problemy teorii i praktiki upravleniya [Problems of theory and practice of management], 6, 17-25

Aganbegian, A.G., Porfir'ev, B.N., Shirov, A.A. (2021). O preodolenii tekushchego krizisa i putiakh razvitiia ekonomiki Rossii [On recovery from the current crisis and development paths of the Russian economy]. In Nauchnye trudy Vol'nogo ehkonomicheskogo obshchestva Rossii [Scientific works of the Free Economic Society of Russia], 227(1), 193-213. DOI: 10.38197/2072-2060-2021-227-1-193-213

Antonova, N.E., Lomakina, N.V. (2020) Resursnye otrasli Khabarovskogo kraia v usloviiakh otritsatel'noi dinamiki ekonomiki [Resource Industries of the Khabarovsk Territory in the Context of Negative Economic Dynamics]. In Regionalistika [Regionalistics], 6, 5-22. DOI: 10.14530/reg.2020.6.5

Bardal, A.B. (2020). The state border between China and Russia: permeability and barriers for international cooperation. J. Sib. Fed. Univ. Humanit. Soc. Sci., 13 (11), 1700-1709. DOI: 10.17516/1997-1370-0676.

Chereshnev, V.A., Tatarkin, A.I., Fedorov, M.V. (eds.) (2012). Ekonomicheskaia bezopasnost' Rossii: uroki krizisa i perspektivy rosta [Economic Security of Russia: Lessons from the Crisis and Growth Prospects]. Yekaterinburg, Institute of Economics UB RAS, $1312 \mathrm{p}$.

FTS Rossii: dannyye ob eksporte-importe Rossii za ianvar'-dekabr' 2020 goda [FCS of Russia: data on export-import of Russia for January-December 2020] (2021). Available at: https://customs.gov.ru/press/ federal/document/267169

Goriunov, A.P. (2011). Vozdeistvie mirovogo finansovogo krizisa na ekonomiku regiona: Khabarovskii krai [The Global Financial Crisis Impact on Khabarovsk Territory's Economy]. In Prostranstvennaia Ekonomika [Spatial Economics], 1, 7-29. DOI: 10.14530/se.2011.1.007-029

Skorlygina, N., Mertsalova, A. (2020). Gruzite vse tovary bochkami [Load all goods in barrels]. Newpaper «Commersant», 222, 03.12.2020 Available at: https://www.kommersant.ru/doc/4595411

Guriev, S., Plekhanov, A., Sonin, K. (2010). Ehkonomicheskii mekhanizm syr'evoi modeli razvitiia [Economics of Development Based on Commodity Revenues]. In Voprosy Ekonomiki [Economic issues], (3), 4-23 DOI: 10.32609/0042-8736-2010-3-4-23

Itog 2020 goda - vremia dividendov [Result of 2020 - time for dividends] (2021) Available at: https://gold.1prime.ru/reviews/20210420/407622.html.

Kravchenko, N.A., Iusupova, A.T. (2020). «Soft» factors in pandemic response: comparative intercountry analysis. J. Sib. Fed. Univ. Humanit. Soc. Sci., 13 (11), 1770-1780. DOI: 10.17516/1997-1370-0682

Kriukov, V.A., Tokarev, A.N. (2019). Contemporary features of innovative development of the Russian mineral resource complex. J. Sib. Fed. Univ. Humanit. Soc. Sci., 12(12), 2193-2208. DOI: 10.17516/1997-1370-0518

Lomakina, N.V. (2016) Mineral'nyi sektor ehkonomiki Dal'nego Vostoka: problemy i vozmozhnosti razvitiia v krizisnyi period [Mineral Sector of Far Eastern Economy: Problems and Possibilities of Development during the Crisis Period]. In Regionalistika [Regionalistics], 3(1), 13-21.

Malkina, M. Yu. (2018). Vklad regionov i otraslei v finansovuiu nestabil'nost' rossiiskoi ekonomiki [Contribution of Regions and their Sectors to the Financial Instability of the Russian Economy]. In Terra Economicus, 16(3), 118-130. DOI: 10.23683/2073-6606-2018-16-3-118-130.

Mikheeva, N.N. (2019). Ekonomicheskaia dinamika rossiiskikh regionov: krizisy i puti vosstanovleniia rosta [Economic Dynamics of Russian Regions: Crises and Ways of Restoring Growth]. In Region: Ekonomika i sociologiia [Region: Economics and Sociology], 109 (2), 56-79. DOI: 10.15372/REG20190203 
Minakir, P.A. (2016). Shoki i instituty: paradoksy rossiiskogo krizisa [Shocks and Institutions: The Paradoxes of Russian Crisis]. In Prostranstvennaia Ekonomika [Spatial Economics], 1, 7-13. DOI: 10.14530/ se.2016.1.007-013

Minakir, P.A. (2020a) Rossiiskaia ekonomika: mezhdu krizisami [Russian Economy: Between Crisis]. In Prostranstvennaia Ekonomika [Spatial Economics], 16(1), 7-23. DOI: 10.14530/se.2020.1.007-023

Minakir, P.A. (2020b) Ekonomika pandemii: rossiiskii put' [The Pandemic Economy: The Russian Way]. In Prostranstvennaia Ekonomika [Spatial Economics], 16(2), 7-18. DOI: 10.14530/se.2020.2.007-018

Pervyi kvartal 2021 goda: nizkii start [Q1 2021: Low start]. (2021). Available at: https://gold.1prime.ru/ analytics/20210413/406226.html

Puffert, D. (2003). Path Dependence. In EH.Net Encyclopedia. Available at: https://eh.net/encyclopedia/path-dependence/ 